DOI: 10.20472/IAC.2018.001.025

\title{
KANJANA WATTHANASIRIKULCHAI
}

Suan Sunandha Rajabhat University, Thailand

NOPADOL BURANANUTH2

Suan Sunandha Rajabhat University, Thailand

\section{ORGANIZATION MANAGEMENT OF THE SUB-DISTRICT ADMINISTRATIVE ORGANIZATION IN HUAY YOD DISTRICT, TRANG PROVINCE, THAILAND BASED ON GOOD GOVERNANCE}

\begin{abstract}
:
The main objectives of this research were to: 1 ) study the opinion level of the officers on the organization management of the sub-district administrative organization in Huay Yod District, Trang Province based on good governance; and 2) to compare the opinion of these officers. A quantitative research methodology was utilized in this study. The research sample was 250 officers of the sub-district administrative organization in Huay Yod District, Trang Province. Data were collected via the use of a questionnaire. The collected data were analyzed with descriptive statistics including frequency, percentage, mean, and standard deviation. T-test was also used to analyze two groups of independent variables and One-Way ANOVA was also used to analyze the data. The research findings showed that: 1 ) in terms of the opinion level of the officers, it was found that the overall opinion and the opinion toward each aspect of good governance including the rule of law, responsibility, participation, morality, accountability and cost effectiveness were rated at a high level; and 2) respondents with different age, education level, income had different opinion on the management based on good governance, with a .01 and .05 level of statistical significance, whereas those with different gender and work position had no difference in their opinion in this issue.
\end{abstract}

\section{Keywords:}

Good Governance, Sub-district Administrative Organization

JEL Classification: Y80 


\section{Background and Significance of the Research}

Good governance is an important concept for the management and government at the present time. This is because globalization and good governance or good management have played a significant role in today's world. The development and evolution of political and government has been focusing more on people, or in other words, people are put as a center on consideration. Having good management system and good governance, thus, is a focus of every divisions and has been utilized in to practice in almost every organization.

During 1996 -2007, a concept of good management system and good governance has been promoted in the Thai society by development agencies both within the country and from other countries as well as academic persons who were aware of the significance and necessity of having good management system and good governance which could lead the country to be developed in a sustainable way. These agencies and academic persons raised the issues of problems and impacts arising from inefficient management and bad governance and encouraged publics to be aware of the importance of having good governance. They tried to determine guidelines to develop good system by providing understanding and brainstorming the ideas from the publics from different organizations. As a result, people and the society rapidly recognized the significance of this issue.

Funds aid organizations and financial organizations which provide loans to other organizations and publics such as the World Bank, and the International Monetary Fund utilize the good governance principles as guidelines for developing countries to practice so that fund approved by these organizations will be used transparently, efficiently and effectively. Although, these countries may have different forms of good governance based on their own context, they follow similar basic principles including participation, accountability, responsibility, and efficiency and effectiveness (Bureekul, 2003)

In order to enhance the efficiency in the management system of local administrative organizations in Thailand so that general publics can receive efficient and equal services, all stakeholders have to take part in the development of the community, reduce their dependence on government subsidies, be flexible and self-reliant in term of finance in a long run. Moreover, they have to provide basic public services which are up to standards for people, and review the process of how power is distributed to related organizations and how duties and responsibilities in governing the community are distributed from the central government to local administrative organizations. This has to be clear and performed according to potential and readiness of each community. The issue of education and public health has to be emphasized as well. Additionally, there should be a clear and accurate system for assessing the potential of each community and such assessment should be performed from independent agencies; mechanism and measures to control and monitor how power is distributed 
should be determined clearly; local administrative organizations should be supported from related organizations to develop a system to provide and manage public services that meet the needs of local people.

Efficient management system and good governance in the local administrative organizations can be achieved through a participatory process in which all stakeholders including the organizations themselves, private sector, and publics have an equal part. The local administrative organization must be given flexibility and freedom to govern their responsible community such as in determining policies and managing personnel, finance, and budget. In addition, the operation of the organizations should be adjusted to be connected with other related organizations and a system to monitor and look after people and community should be established (The $12^{\text {th }}$ National Economic and Social Development, B.E. 2017-2021).

Based on the above-mentioned issues, the researcher was interested to study the management system of the sub-district administrative organization in Huay Yod District, Trang Province based on six principles of good governance including the rule of law, morality, accountability, participation, responsibility, and cost effectiveness. The findings from this study were expected to encourage officers in the local administrative organizations to be aware of their rights as well as their duties and responsibilities based on the good governance principles so that people in the areas can monitor them and can be part of the management. This is interesting in the researcher's point of view. The findings are also expected to be beneficial for the management of local administrative organizations in the study area because if it is managed based on good governance, efficiency and good results for the community could be achieved and a foundation for democracy could be established.

\section{Research Objectives}

The primary objectives of this study were to:

1. examine the opinion level of officers on the organization management of the subdistrict administrative organization in Huay Yod District, Trang Province based on good governance; and

2. compare the opinion of these officers on this specific issue. 


\section{Scope of Research}

\section{Scope of content}

This study aimed to examine on the issues of local administration and good governance principles.

\section{Scope on research population}

Population of this research were officers of the sub-district administrative organization in Huay Yod District, Trang Province. There are 673 officers at the time of the conducting this study.

Population were selected by simple random sampling by using Tara Yamane Formula with a confidential level at $95 \%$ and error of no higher than $5 \%$. As a result, 250 respondents were selected.

\section{Scopes on research variables}

There are two groups of variables in this study:

Independent variables consist of demographic background of the respondents including gender, age, educational level, position at work, and income per month.

Dependent variables consist of management based on good governance which include the rule of law, morality, accountability, participation, responsibility, and cost effectiveness.

\section{Research Methodology}

This study employed a quantitative research methodology. Data were collected with the use of a questionnaire. This questionnaire was developed by the researcher from the study and review of related concepts and theories. It contained two parts. The first part aimed to collect the demographic data of the respondents, and the second focused on opinion on the management according good governance principles.

Collected data were analyzed with including frequency, percentage, mean, and standard deviation. T-test was also used to analyze two groups of independent variables and One-Way ANOVA was also used to analyze the data.

\section{Research Findings}

Based on the analysis of data, it was found that in terms of demographic background of the respondents, most of them were female (57.2 percent) and aged between 41-50 years (41.2 percent). They were generally graduated with bachelor's degree (70.8 
percent), worked as government officers (56.0 percent), received around 15,001 20,000 Bath per month (36.4 percent).

In terms of the respondents' opinion on the management based on good governance of the sub-district administrative organization in Huay Yod District, Trang Province, it was found that overall the respondents had positive opinion towards it as it was rated at a very high level. Moreover, each aspect of the good governance principles including the rule of law, morality, accountability, participation, responsibility, and cost effectiveness, was also rated at a very high level. This finding is consistent with the study of Sinsuwan, (2015) which study the management based on good governance of the sub-districts in Muang District, Chon Buri Province, Thailand. This study revealed that the overall management of the organization was rated at a high level. The most important aspect of good governance principles was morality, followed by cost effectiveness, the rule of law, participation, accountability and responsibility respectively.

The study also found that demographic background of the officers had an influence on their opinion on the management of the organization based on good governance. Specifically, those with different age had different opinion on the aspect of accountability and responsibility.

In addition, officers with different educational level was found to be different in their opinion on the importance of participation, and responsibility and those with different income per month had different idea on the importance of responsibility. Officers which different gender and work position were found to had do difference in their opinion in this issue.

\section{References}

Bureekul, T. (2003). Governance: A New Approach to Public Administration. King Prajadhipok's Institute journal, 1(2)

Pakdeejit, R. (2012). Good governance, public and private management. Bangkok: Chulalongkorn University Press.

Phuangngam, K. (2001). Thai local Administration. Bangkok: Winyuchon

Sinsuwan, U. (2015). An administration based on of the principles of good governance in Muang District of Chonburi, Chonburi. Unpublished independent study. Chonburi: Burapha University.

Srijunpetch, S. (2010). Good governance principles. Journal of Business Administration, 33(125) 